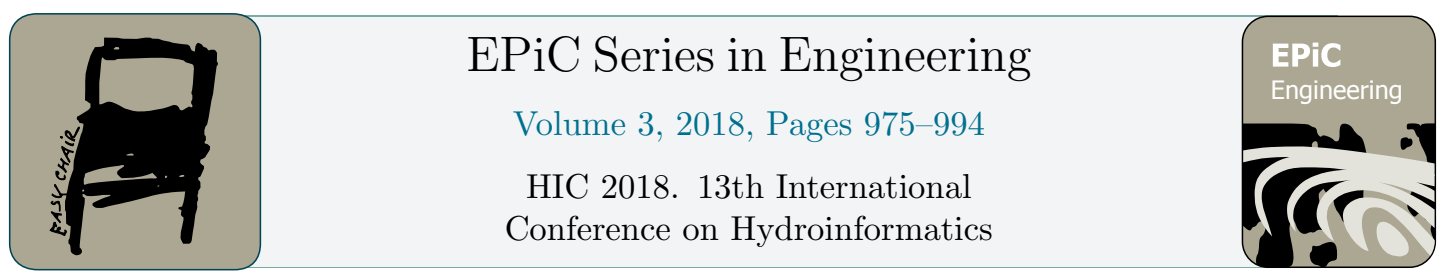

\title{
Assessment of Water Demand for Bioethanol Production from Biomass in China
}

\author{
Shan Jiang, Lizhen Wang, Yong Zhao, Yizi Shang, Qingming Wang, \\ ${ }^{1}$ a. State Key Laboratory of Simulation and Regulation of Water Cycles in River \\ Basin, China Institute of Water Resources and Hydropower Research, Beijing \\ 100038, China
}

Corresponding author: shan_jiang87@126.con

\begin{abstract}
China is an energy starved country that has faced a severe energy crisis for the last few decades. In response to China's increasing dependence on non-renewable fuels, the Chinese government has discussed current and potential biomass energy resources as well as energy conversion and promotion policies. Bioethanol production has proven to be environmentally friendly and energy-efficient and is a potentially important source of renewable fuels. However, the uneven distribution of water and the implementation of the Three Red Lines water conservation policies may limit the development of bioethanol in China. From the perspective of water footprint (WF), this paper analyzes the water requirements of producing bioethanol from crop straws, and shows that water consumption in the bioethanol conversion stage is less than that in the crop growth stage; in other words, producing bioethanol from crop straws may be more water-efficient than that from grains or non-grain crop because water that would be consumed for grain growth is already being allocated to the agricultural sector. There is an abundance of crop straws of approximately 150.71 million tons that can be used for bio-ethanol production in China; if converted, 41.83 billion L ethanol would be produced annually, and an amount equal to 4 times China's fuel ethanol production in 2014. According to a crop straws and water resource conditions, the provinces of Jilin, Shandong, Henan and Sichuan are the best for developing bioethanol from crop straws however, variations in the local availability of water resources and crop straws prevent us from drawing immediate conclusions about which crop straws would be most suitable for bioethanol production in China.
\end{abstract}

Keywords: Biomass energy, Bioethanol, Crop straws, Water footprint, Water resources. 


\section{Introduction}

Due to the twin crises of greenhouse gas emissions and growing energy demand, worldwide countries have actively developed alternative energy plans to reduce their dependence on fossil-based energy [1,2]. Biomass energy will undoubtedly play an important role in tackling the world's energy consumption problems [3]. According to the IEA World Energy Outlook 2015, biomass constitutes approximately 15\% of total primary energy consumption and continues to expand rapidly. Currently, $84 \%$ of the world's total ethanol from biomass is already being generated in the US and Brazil. However, there remain significant challenges to be addressed because continuing the use of food grains as feedstock will increase already fierce competition for arable land and water with food production and adversely affect market prices and food security $[4,5]$.

To estimate the potential for biomass development in the future, bioethanol production using various feedstock options have received widespread attention. Detailed descriptions and quantitative analyses of biomass for bioethanol production show that the biomass resource base is large enough to cover a substantial share of energy consumption [5]. In addition, several alternative feedstock sources are being investigated as solutions to meet energy demand. For example, reed and woody biomass can both be used to produce cellulosic ethanol [6,7]. Li et al. assessed the potential ethanol feedstock supply potential of non-food crops within the PRC (People's Republic of China) and found that sweet sorghum has the greatest potential [8]. Microalgae are potentially important sources of liquid renewable energy but are not yet produced on a large scale [9]. Tian et al. have explored how cassava, sweet potato and similar root crops could be developed as bioethanol feedstock on unused land suitable to their geographical and agricultural production requirements [10]. All of these studies suggest that non-cereal feedstock have huge potential for the development of bioethanol production, but such development would increase food prices, causing greater food insecurity, while non-food feedstock may compete for water and land resources with food crops.

There has been much debate over how large-scale biomass resources should be developed [11]. In particular, China is the one of the countries with severe water scarcity in the world, the freshwater resources per capita in China is only around a quarter of the global average and water resources per unit irrigated area is one fifth of the world average [12]. Extreme uneven distribution of water resources has aggravated the difficulty of water resources utilization, limiting the further increase of agricultural production [13]. At mean time, the "three red lines" policy is fully implemented in 2012, which sets targets of total maximum blue water consumption ( 670 billion $\mathrm{m}^{3}$ in 2020) [14], this is resource constraints for bioethanol development in China. Bioethanol production from crop residues, by-products of farming, could conserve water and land resources without major adverse effects on the nation's food supply [15]. A variety of methods have been assessed and reviewed for the conversion of 
lignocellulose into bioethanol [16]. Although many studies have assessed the amount and distribution of crop residues available for conversion into biofuels [17-19], these studies rarely take water resources or the type of crop residue into consideration.

Water and energy both drive and constrain human development, and water is a major input to bioethanol production that must be considered [20]. The water footprint (WF), introduced by Hoekstra [21], is indicator could measure water use in relation to production or consumption and tool for calculating. The research on WF has been deepened in order to solve the problem of water shortage in China [22,23]. WF computations are used to provide detailed process-based evaluations of water requirements of various food and non-food feedstock for bioethanol [24,25]. These evaluations are helpful for selecting the most water-efficient crops and the best regions in which to produce bioenergy [26,27] and more comprehensively analyze all links associated with the consumption of water. It is important to consider the different regions' level of development, as well as the impact of bioethanol production upon competition for water; this article focuses on Chinese mainland, which consists of 31 provinces, autonomous regions and municipal cities, and assesses water consumption in bioethanol production from crop residues in China.

This paper is structured as follows: Section 2 illustrates the proposed methodology, and Section 3 makes an estimate of the availability of crop straws based bioethanol, calculating average green- and blue- WFs of the growth and conversion of 10 crop straws categories in China, as well as the withdrawal-to-availability ratio of different provinces in China, while Section 4 examines the water demand of bioethanol production based on the bioethanol development plan set by the government for 2020, and bioethanol development in the rich straw resources provinces. Finally, some conclusions are presented in Sections 5. This paper will contribute to a shift towards bioenergy production by identifying the most suitable provinces for bioethanol production and evaluating the appropriate scale of straw-based bioethanol development in China.

\section{Method and Material}

\subsection{The frame of bio-ethanol production}

To calculate the scale of bio-ethanol development, a water demand/water limitation (WDWL) model is devised to represent the whole process (shown in Fig. 1). The first module is divided into two water use processes including crop growth stage and straw conversion stage water use. Water use in crop growth stage refers to the water consumed by crop growth, while water use in straw conversion stage refers to the water directly consumed by bio-ethanol production. The second module describes the limitation of regional water resources by local precipitation, water resource stress and the water resources available in different provinces. Taking domestic water, agricultural water, industrial water and ecological water use into account, the model must determine whether available water resources can support the 
development of bio-ethanol from crop straws, so the second module is designed to evaluate regional water resources.

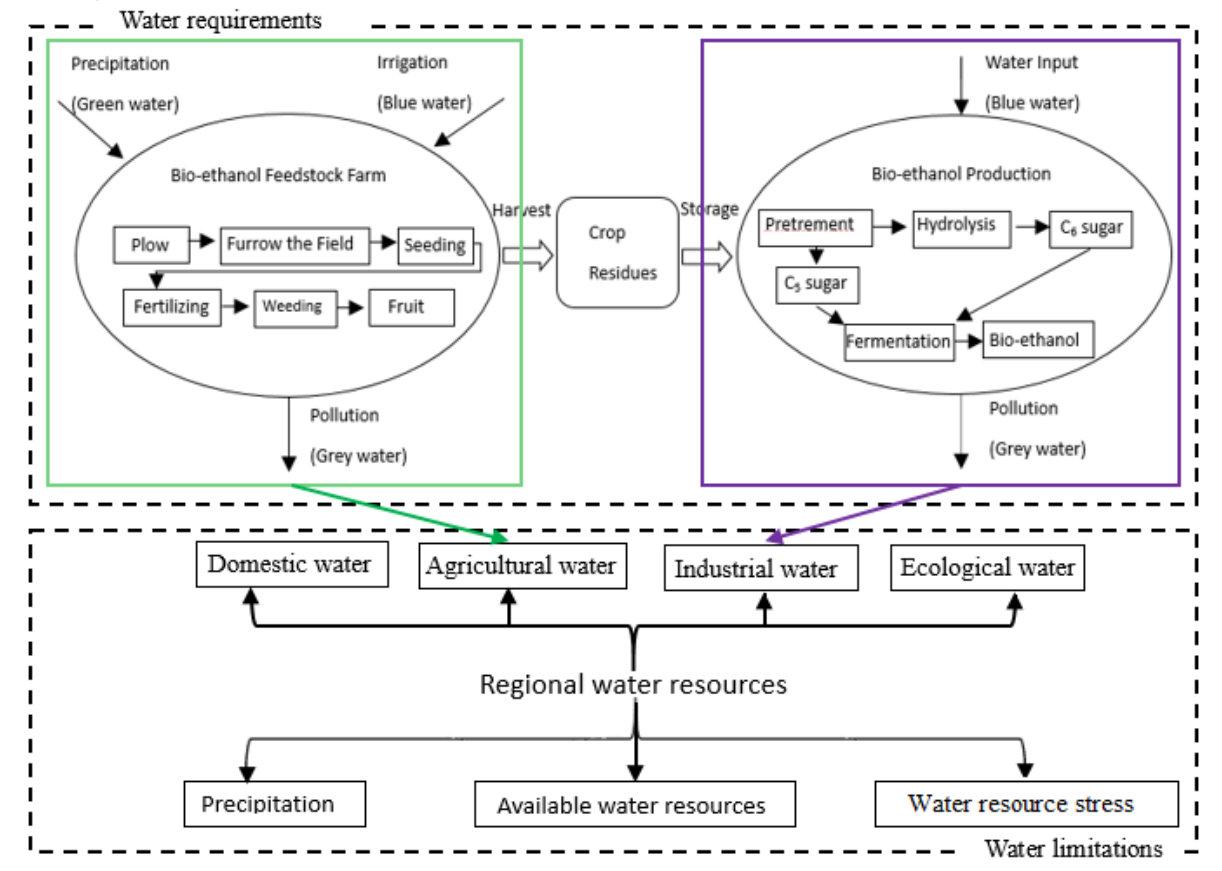

Fig. 1 Schema of water demand and water limitation (WDWL) at the regional level

\subsection{Method}

\subsubsection{The yields of crop straws}

The national utilization plan of straw resources involves not only the efficient utilization of renewable resources from the whole agroecosystem but also a shift in the energy structure. The crops studied in this paper include rice, wheat, maize, beans, tubers, oil-bearing crops (groundnut, rapeseed), cotton, and sugar crops (sugar cane, sugar beet). The estimated ton of each crop's yield $\left(\mathrm{W}_{\mathrm{cy}, \mathrm{i}}\right)$ in China is the average between 2005 and 2014. The crop-to-residues index (CRI) is defined as the ratio of the dry weight of residues to the total crop weight [3]. The yield of each crop residue $\left(\mathrm{W}_{\mathrm{i}}\right)$ can be calculated by the following formula:

$\mathrm{W}_{\mathrm{i}}=\mathrm{W}_{\mathrm{cy}, \mathrm{i}} \times \mathrm{CRI}$

\subsubsection{WF in bioethanol production}

This study focuses on comparison WF in different stages and discussion about water availability, and only calculates green and blue components of WF. The blue WF $\left(\mathrm{m}^{3} /\right.$ ton $)$ refers to the volume of surface and groundwater consumed to produce a 
good; the green WF ( $\mathrm{m}^{3} /$ ton) refers to the amount of rainwater consumed [24]. There are crop growth and refinery conversion stages to consume water resources.

\section{WF in crop growth}

This paper takes a complete growing season of the plant into account based on FAO program CROPWAT model to calculate water demand of crop. The core of CROPWAT is Penman-Monteith method which is believed to be able to estimate potential evapotranspiration more realistically than other methods [28]. The formula of Penman-Monteith method is:

$$
\text { ETo }=\frac{0.408 \Delta(\mathrm{Rn}-\mathrm{G})+\gamma \times \frac{900}{(\mathrm{~T}+273)} \times \mathrm{U}_{2} \times\left(\mathrm{e}_{\mathrm{s}}-\mathrm{e}_{\mathrm{n}}\right)}{\Delta+\gamma\left(1+0.34 \mathrm{U}_{2}\right)}
$$

Where $\mathrm{ET}_{\mathrm{o}}$ is reference evapotranspiration $(\mathrm{mm}), \Delta$ is the slope of the vapor pressure curve $\left(\mathrm{kPa} /{ }^{\circ} \mathrm{C}\right), \gamma$ is the psychrometric constant $\left(\mathrm{kPa} /{ }^{\circ} \mathrm{C}\right), \mathrm{Rn}$ is the net radiation at the crop surface $(\mathrm{MJ} / \mathrm{m} 2 \mathrm{~d}), \mathrm{T}$ is the average air temperature $\left({ }^{\circ} \mathrm{C}\right), \mathrm{U}_{2}$ is the wind speed measured at $2 \mathrm{~m}$ height $(\mathrm{m} / \mathrm{s})$, es is the saturation vapor pressure $(\mathrm{kPa})$ and en is the actual vapor pressure $(\mathrm{kPa}), \mathrm{P}$ is the gross monthly rainfall.

The total crop water demand (CWR) should compensate the evapotranspiration loss from the cropped field [29], which associated with reference crop evapotranspiration $\left(\mathrm{ET}_{\mathrm{o}}\right)$ which is estimated by Penman-Monteith model and the crop coefficient $\left(\mathrm{K}_{\mathrm{c}}\right)$. In CROPWAT model, Effective Rain ( $\mathrm{P}$ eff) can be calculated by USDA, SCS model.

$$
\begin{aligned}
C W R & =E T O \times K c
\end{aligned}
$$

As usual the irrigation water requirements basically represents the difference between the CWR and P eff. When Peff is more than CWR, the water demand of crop could total depend rainfall, there no need irrigation. WF crop, blue is the total irrigation water used during the growing period, which is dependent on the amount of green water used and actual irrigation water (IR). In practical operating, crops are most time under the condition of insufficient irrigation. When the actual irrigation is less than the difference between $\mathrm{CWR}$ and $\mathrm{P}_{\mathrm{eff}}$, the actual irrigation is blue water for crop growth. $\mathrm{WF}$ green $=\left[10 \times \min \left(\mathrm{CWR}, \mathrm{P}_{\text {eff }}\right) \times \mathrm{A}\right] / \mathrm{Wi}$

WF blue $=\left\{\begin{array}{cl}0 & 0>C W R-P_{\text {eff }} \\ 10 \times \min (I R, C W R-P \text { eff, }) & \times \mathrm{A}] / \text { Wi } \quad 0<C W R-P_{\text {eff }}(6)\end{array}\right.$ 
Where $\mathrm{A}$ is the area planted with crops (ha) and $\mathrm{W}$ is the yield of crop straw (tons). The total WF can be calculated as flow:

$$
\mathrm{WF}_{\text {straw }}=\mathrm{WF} \text { straw. green }+\mathrm{WF}_{\text {straw, blue }}
$$

There is bioethanol conversion rates ( $\mathrm{f}_{\text {ethanol}}$ ) (ton straw/ $\mathrm{L}$ ethanol) [1] to replace the relationship between crop straw and the volume of ethanol which is produced by crop straws. The WF in crop growth stage could be shown as follow:

$\mathrm{WF}\left(\mathrm{L}_{\text {water }} / \mathrm{L}_{\text {ethanol }}\right)=\mathrm{WF}\left(\mathrm{m}^{3} /\right.$ ton $) \times \mathrm{f}$ ethanol $\left(\right.$ ton $\left./ \mathrm{L}_{\text {ethanol }}\right) \times 103\left(\mathrm{~L}_{\text {water }} / \mathrm{m}^{3}\right)$

\section{WF in refinery conversion stages}

Surface water and ground water in the conversion stage used for bio-refining is all blue water; there is no green water during the production process. The value of WF bo, blue $\left(\mathrm{L}_{\text {water }} / \mathrm{L}_{\text {ethanol }}\right)$ is derived from the total volume of freshwater $\left(\mathrm{W}_{\mathrm{bo}}\right)$ used during the production process and is divided by the volume of bioethanol produced, Le.

$\mathrm{WF}_{\text {bo blue }}=\frac{\mathrm{W}_{\text {bo }}}{L_{\mathrm{e}}}(9)$

\subsection{3 withdrawal-to-availability ratio (WTA)}

China faces many serious water-related problems, including water shortages and water pollution, and the government has introduced the Three Red Lines policies for the sustainable development of water resources in response [30]. These policies were fully implemented in 2012 and set regional and national targets for total water use, water use efficiency for industry and agriculture, and water quality improvements. China aims to restrain its total water consumption below 670 billion $\mathrm{m}^{3}$ by 2020.The withdrawal-to-availability ratio (WTA), also known as the critical ratio, reflects the balance of water demands and water availability [31]. Where WW represents water withdrawals in 2014, and WA is the most ambitious total water consumption target for 2020 .

$\mathrm{WTA}=\frac{\mathrm{WW}}{\mathrm{WA}}$

\subsection{Data sources}

The data sources used in this paper include (1) Climate data come from 820 meteorological stations of the Chinese ground climate data. The majority of the stations have complete record of climatic variables from 1955 to 2014, such as maximum and minimum air temperature at $2 \mathrm{~m}$ height, precipitation, relative humidity, wind speed and sunshine duration at a daily time step, which is required for green and blue water estimate; 
(2) The agricultural yield of different crops in the nation and regions could be obtained from Statistical year books, such as China Agricultural Statistical Yearbook and China Statistical Yearbook.

(3) The Water Resources Bulletin issued by China Ministry of Water Resources contains water supply and water use by years, as well as irrigation water use, which is used to estimate water withdrawal and IR based on the ration of the area sown to the total area planted. The total control refers to delimitation (initial water allocation) of the quantity of water resources available for provinces (autonomous regions and municipalities) could be obtained from the most stringent water resources management system.

(4) The targets of bioethanol development could refer to national plans, including the 12th-Five-Year Plan for Renewable Energy Development and Medium- and LongTerm Plan for Renewable Energy,

(5) some parameters could be obtained from literature surveys, such as crop coefficient $\left(\mathrm{K}_{\mathrm{C}}\right)$, crop-to-residue index $(\mathrm{CRI})$ and water consumption rates in crop straw-to-bioethanol production processes ( $\left.f_{\text {ethanol}}\right)$.

\section{Result}

\subsection{Spatial distribution of straw biomass in China}

Estimates of straws in China are calculated based on crop yield and CRI. CRI for each type of crops in China are derived from previous literatures [3,32]. The total yield of crop straws in China is estimated to be approximately 846.71 million tons per year. The three main straw are maize, rice and wheat, which account for $80 \%$ together and $42 \%, 23 \%$ and 15\%, separately (Table 1). Due to differences in climate, socioeconomic development and traditional customs, there are huge differences among planting preferences between regions and there is notable regional disparity in the straw distribution. Rice is the staple food of southern China, so rice straws are abundant in Hunan, Jiangsu and Hubei Provinces. Wheat and maize are the main foods in northern China, so straws of wheat and maize are rich in Heilongjiang, Inner Mongolia, Hebei and Jilin Provinces. Additionally, straws of sugarcane are rich in Guangxi, Yunnan and Guangdong Provinces, with the percentage as high as $92 \%$ of national output of sugarcane straws. Hubei, Hunan, Sichuan and Anhui Provinces have abundant straws of oil crops. 
Table 1 average crop straws yield of different crop in China from 2005 to 2014

\begin{tabular}{ccccc}
\hline Crop & $\begin{array}{c}\text { Sown } \\
\text { (million ha•y- } \\
\text { 1) }\end{array}$ & $\begin{array}{c}\text { Yield } \\
\text { (million ton•y- }\end{array}$ & CRI & $\begin{array}{c}\text { Residues } \\
\text { (million ton•y- } \\
\text { 1) }\end{array}$ \\
\hline Rice & 29.63 & 194.65 & 1.0 & 194.65 \\
Wheat & 23.90 & 114.45 & 1.1 & 125.90 \\
Maize & 31.99 & 178.29 & 2.0 & 356.59 \\
Beans & 11.09 & 18.61 & 1.7 & 31.64 \\
Tubers & 8.70 & 31.30 & 1.0 & 31.30 \\
Groundnuts & 4.42 & 6.66 & 1.5 & 9.99 \\
Rapeseed & 7.00 & 15.11 & 3.0 & 45.33 \\
Cotton & 5.06 & 13.01 & 3.0 & 39.03 \\
Sugarcane & 1.65 & 113.86 & 0.1 & 11.39 \\
Sugar beet & 0.20 & 9.06 & 0.1 & 0.91 \\
Total & 124.22 & 697.30 & $/$ & 846.71 \\
\hline
\end{tabular}

The spatial distribution of crop straws is influenced by climate conditions and physical properties (Fig. 2), crop straws distribution varies from province to province and the production is concentrated in China's northeastern region, the North China Plain, and the Chengdu Plain. The provincial statistical analysis results show that the majority of straw production is concentrated in Heilongjiang, Henan, and Shandong Provinces. Together, these three provinces account for almost $28 \%$ of the entire nation's production. The provinces with the least crop straws are Tibet, Shanghai, Beijing, Qinghai and Tianjin, which is less than 3 million ton. Take cost efficiency into consideration, uncollectable crop straws, such as low density, small yield or scatter, could be used for animal feed, fertilizer and so on, which are important ways for direct utilization of crop straws. 


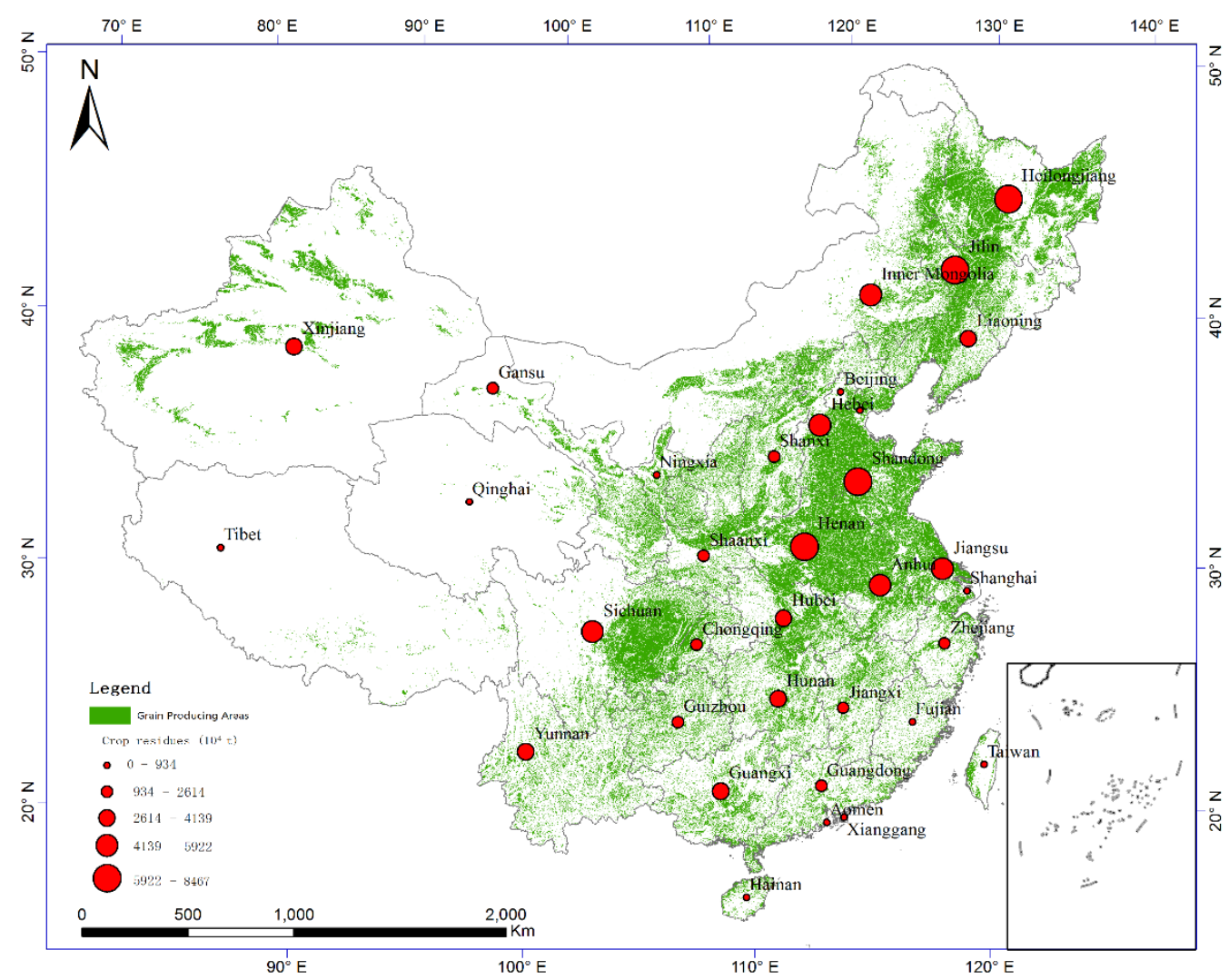

Fig 2 Map of farmland distribution and crop straws of different regions in China

\subsection{WF in the crop growth stage}

Calculating the WF of crop growth not only contributes to a more comprehensive understanding of the water requirements of crop residue-based bioethanol but also to comparisons of water consumption during crop growth with conversion. On a national scale, crops with high yield or large crop straws coefficients have small WF, while crops with low yield or small crop straw coefficients have high WF. Table 2 shows the WF of different crop straws, including green and blue WF, and illustrates the water use efficiency in the crop growth stage. Cereal crop straws are the most water-efficient, but variation in WF between cereals is also large; the WF of maize straw is relatively small $\left(402 \mathrm{~m}^{3} / \mathrm{ton}\right)$, while that for rice straw is relatively large $\left(903 \mathrm{~m}^{3} / \mathrm{ton}\right)$. For oil plants, we find that the WF of rapeseed straw is $952 \mathrm{~m}^{3} /$ ton and that of groundnut straw is $1001.94 \mathrm{~m}^{3} /$ ton. One ton tuber straw requires $1395 \mathrm{~m}^{3}$ water, and one ton bean straw takes $1302 \mathrm{~m}^{3}$ water. The WF of sugarcane straws is $1685 \mathrm{~m}^{3} /$ ton, which makes it the least water-efficient bioethanol feedstock, followed by $1609 \mathrm{~m}^{3} /$ ton for cotton straw. Cotton and sugar beet straws are the raw materials showing with the largest blue WF. 
Table 2. National average WF of crop straws in China Unit: $\mathrm{m} 3 /$ ton

\begin{tabular}{cccc}
\hline Source of straws & Green WF & Blue WF & Total WF \\
\hline Rice & 687 & 217 & 903 \\
Wheat & 492 & 282 & 775 \\
Maize & 327 & 75 & 402 \\
Beans & 927 & 374 & 1302 \\
Tubers & 1083 & 312 & 1395 \\
Peanut & 806 & 196 & 1002 \\
Rapeseed & 746 & 205 & 952 \\
Cotton & 782 & 827 & 1609 \\
Sugarcane & 1294 & 391 & 1685 \\
Sugar beet & 407 & 548 & 955 \\
\hline
\end{tabular}

Crop straws are inevitable agricultural byproducts. There are differences among provinces in terms of WFs due to differences in climatic condition, crop yields and crop management between provinces. Fig. 3 shows the average WF of 10 types of bioethanol providing crops, including blue and green WFs, and illustrates the province differences. Qinghai, Gansu, Xizang, Ningxia and Xinjiang Provinces have high blue water footprints, which indicates their heavy dependence on artificial irrigation for crop growth. The green WF component makes up more than $50 \%$ of the WF in other provinces, indicating that crops in these regions are more reliant on rain water, rendering them better suited to meet a low-input selection criterion. The WF in the southern regions is larger than that in the northern regions. 


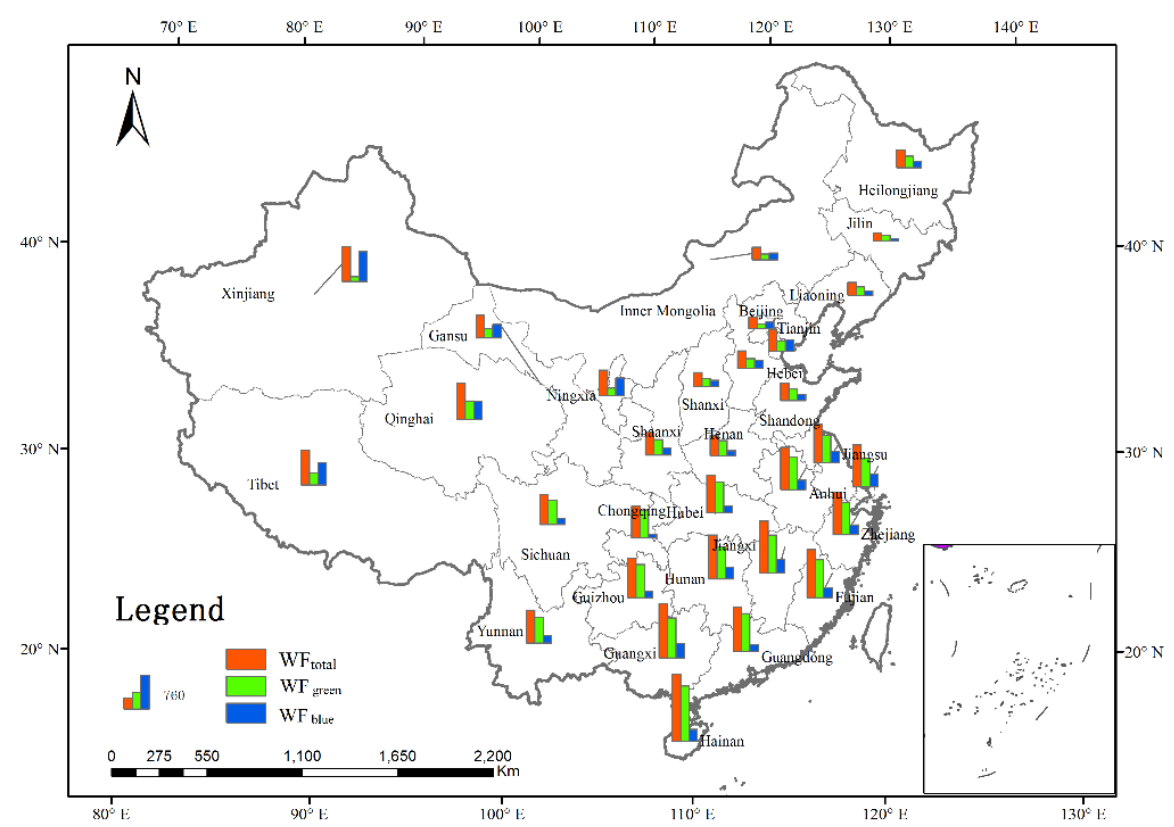

Fig 3 average WF of 10 crops at the provincial level in China

\subsection{WF in bioethanol production stage}

Current literatures about water consumption of bioethanol from crop straws are more likely to focus on maize, wheat and rice straw due to comment materials for biomass. This paper puts other crops straws into cellulosic feedstock. Consumption analysis, based on the water consumed (in L) per L bioethanol, shows that water consumption in the conversion stage is negligibly smaller than that in the crop growth stage that water consumption in the grow crop stage is more than 30 times in the conversion stage, and maize straw are the most water-efficient (table 3). If 846.71 million tons crop straws are used for bioethanol, there will acquire 235 billion $\mathrm{L}$ bioethanol. In the process of crop growth, blue water is consumed 175 billion, however, this part of blue water has been calculated in agricultural water use, and there will consume 1.6 billion for conversion. 
Table 3. Water footprints of bioethanol production

\begin{tabular}{|c|c|c|c|c|c|c|}
\hline \multirow[b]{2}{*}{ Items } & \multicolumn{4}{|c|}{ WF in crop grow stage } & \multicolumn{2}{|c|}{$\begin{array}{c}\text { WF in straw } \\
\text { conversion stage }\end{array}$} \\
\hline & $\begin{array}{c}\text { Blue } \\
\text { WF } \\
\left(\mathrm{m}^{3} / \text { ton }\right)\end{array}$ & $\begin{array}{c}\text { Ethanol } \\
\text { conversion } \\
\text { rate } \\
\left.\text { ( } \mathrm{L}_{\text {ethanol }} / \text { ton }\right)\end{array}$ & Source & $\begin{array}{c}\text { WF ( } \mathbf{L}_{\text {water }} / \mathbf{L} \\
\text { ethanol) }\end{array}$ & $\begin{array}{c}\text { Blue } \\
\text { WF (L } \\
\text { water } / \text { L } \\
\text { ethanol) }\end{array}$ & Source \\
\hline Rice & 216.59 & 200 & {$[1]$} & 1082.96 & 5.4 & {$[33]$} \\
\hline Wheat & 282.34 & 246 & \multirow{2}{*}[34]{} & 1147.74 & 6.17 & \multirow{2}{*}[35]{} \\
\hline Maize & 75.32 & 375 & & 200.85 & 6.28 & \\
\hline Beans & 374.19 & \multirow{5}{*}{183} & & 2044.73 & \multirow{7}{*}{11.59} & \multirow{7}{*}{$\begin{array}{c}{[40-} \\
43]\end{array}$} \\
\hline Tubers & 311.71 & & & 1703.31 & & \\
\hline Groundnut & 195.69 & & $\begin{array}{l}{[35-} \\
39]\end{array}$ & 1069.36 & & \\
\hline Rapeseed & 205.33 & & & 1122.02 & & \\
\hline Cotton & 826.84 & & & 4518.26 & & \\
\hline Sugarcane & 390.76 & 220 & {$[1]$} & 1776.19 & & \\
\hline Sugar beet & 547.68 & 183 & $\begin{array}{l}{[35-} \\
39]\end{array}$ & 2992.81 & & \\
\hline
\end{tabular}

\subsection{Water limitation for bioethanol development}

Water withdraw is about 609 billion $\mathrm{m}^{3}$ in 2014 which accounts for $91 \%$ of total water consumption of the Three Red Lines water policy targets in 2020. According to Figure 4, only three provinces with water withdrawal are under $70 \%$ of the Three Red Line targets set for 2020 . There are 11 provinces which water withdrawal have exceed the $90 \%$ of targets in 2020 , will face more serious water restrictions, and water withdrawal in 5 provinces have been more than total amount control of water resources, such as Heilongjiang, Jiangsu, Anhui, Gansu and Xinjiang Province, where are the major agricultural provinces. If developing grain-based or non-grain ethanol in these provinces, agricultural irrigation water is bound to increase and water resources is the important limitation. Compared water consumption in the crop growth stage and conversion stage, crop straws have the potential to provide a strategic sources of bioethanol. 


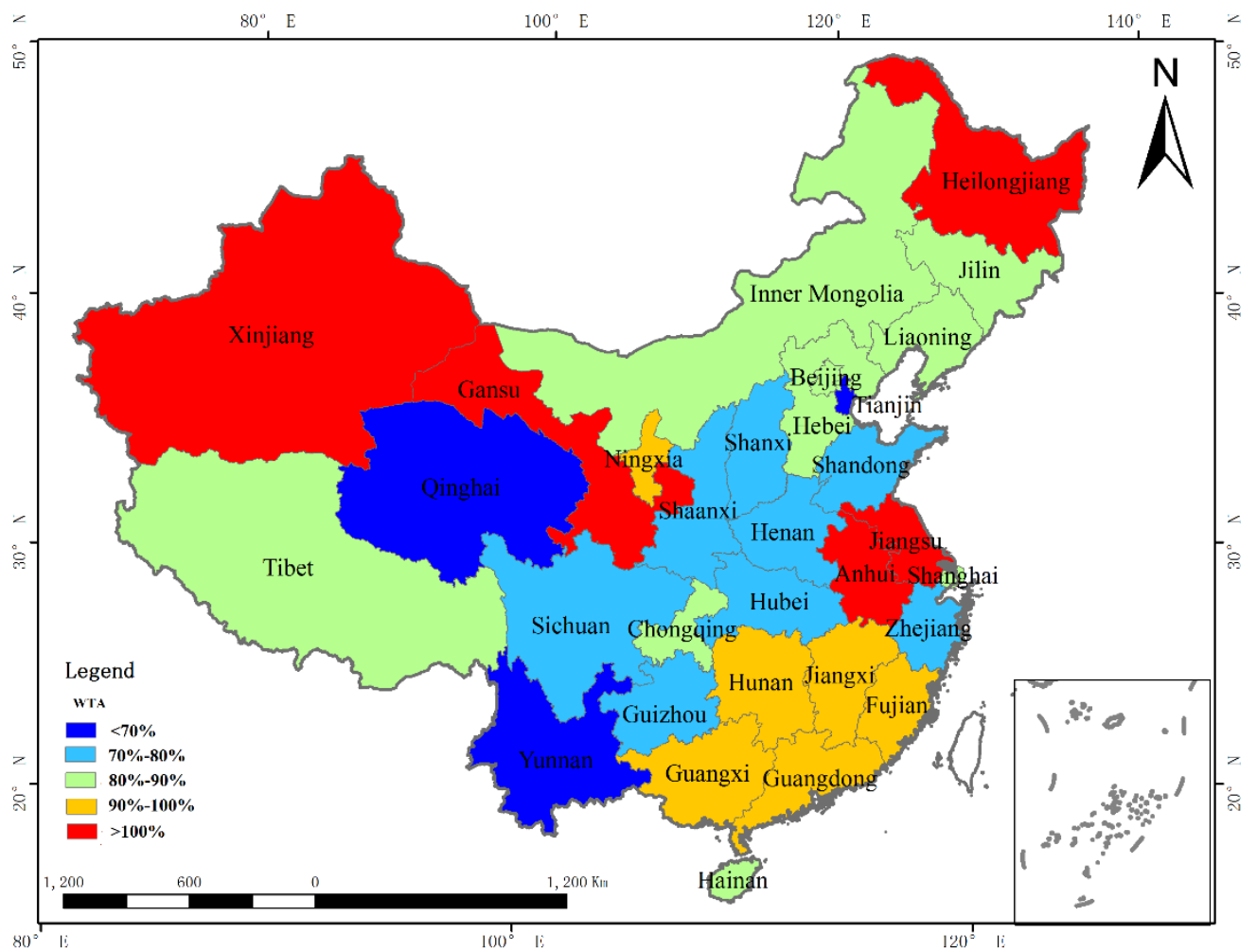

Fig 4 spatial distribution of WTA in different provinces

\section{Discussion and Conclusion}

\subsection{Uncertainties}

Water consumption in straws conversion stage is much smaller than that in crop growth stage, which illustrates lots of extra water resources will be consumed for crop growing, this conclusion could be found in [44-46]. Bioenergy crops would compete for land and water resources with food production causing food security challenges, while crop straws can reduce the competition with crops and increase the efficiency of agricultural residue use. Although China has vast crop straws and bioethanol is favorable for environmental protection and sustainable development, there are some uncertainties for developing bioethanol from crop straws, such as improvement in water productivities of production technology, water consumption during collection and transportation of crop straws because the distribution of the crop is relatively dispersed so that collecting crop straws will require many materials and resources. At the same time, production cost is significant factors for developing bioethanol from crop straws at current stage. However, this paper provides some insights into the possible consequences of bioethanol development from crop straws under various types of crop straws, and water consumption. 


\subsection{Water demand for bio-ethanol from straws in 2020}

According to its Medium-term and Long-term Development Plan for Renewable Energy, China is expected to produce 10 million tons of bioethanol per year by 2020 . Consequently, we assume that 1 million ton of bioethanol will be obtained from straws by 2020 , equal to 1.27 billion L ethanol. Table 3 shows straws from maize, rice, wheat and rapeseed can meet the 2020 consumption target from the perspective of total crop straw yield; the yields of the other crop straws are too low to meet the development plan in 2020 which it is more efficient for these straws to be left in the field as fertilizer or animal fodder. The water consumption of maize growth is the smallest; if the projected demand for bioethanol can be fulfilled by production from maize straw, $3.39 \times 10^{6}$ tons of straw accounting for $0.8 \%$ of the total maize straw production in China will be required, and the process of bioethanol production will requires 11.09 $\times 10^{8} \mathrm{~m}^{3}$ of green water, $2.63 \times 10^{8} \mathrm{~m}^{3}$ of blue water. However, water consumption in the crop straw growth stage has been calculated as part of agricultural water consumption; the additional blue water demand in the conversion stage for 2020 targets is $0.08 \times 10^{8} \mathrm{~m}^{3}$. These figures also show that bioethanol from crop straws is more waterefficient than bioethanol from grain.

Table 4. Water requirements for the targeted production of bioethanol in 2020

\begin{tabular}{cccccc}
\hline Crop & $\begin{array}{c}\text { Available } \\
\text { straws for } \\
\text { bioethanol } \\
\text { (million tons) }\end{array}$ & $\begin{array}{c}\text { Straw use for } \\
\text { development } \\
\text { plan in 2020 } \\
\text { (million tons) }\end{array}$ & \begin{tabular}{c} 
water \\
requirement in \\
crop grow stage \\
\cline { 4 - 6 }
\end{tabular} & $\begin{array}{c}\text { (10 } \mathbf{~ m}^{\mathbf{3}} \mathbf{)} \\
\text { Green }\end{array}$ & $\begin{array}{c}\text { Blue } \\
\text { in conversion stage } \\
\left.\mathbf{( 1 0}^{\mathbf{8}} \mathbf{~ m}^{\mathbf{3}}\right)\end{array}$ \\
\hline Rice & 36.35 & 6.35 & 43.62 & 13.75 & Blue \\
Wheat & 23.70 & 5.16 & 25.41 & 14.58 & 0.0686 \\
Maize & 73.20 & 3.39 & 11.09 & 2.55 & 0.0784 \\
Beans & 5.24 & & 64.36 & 25.97 & \\
Tubers & 5.86 & & 75.16 & 21.63 & \\
Groundnut & 4.46 & 6.94 & 55.95 & 13.58 & \\
Rapeseed & 7.48 & & 51.78 & 14.25 & 0.1472 \\
Cotton & 3.65 & & 54.30 & 57.38 & \\
Sugarcane & 2.19 & 5.77 & 74.70 & 22.56 & \\
Sugar beet & 0.21 & 6.94 & 28.24 & 38.01 & \\
\hline
\end{tabular}

\subsection{Water demand for bioethanol in the rich straw resources provinces}

The ratio of water use in the agricultural, industrial and domestic sectors is currently kept at $6.3: 2.3: 1.4$. The proportion of agricultural water use will decrease to $60 \%$ of the total by 2030 , with corresponding increases in the industrial and domestic 
water use proportions. As a result, water allotments for agriculture will be nearly impossible to increase and the yield of agriculture is stable. The main approach of straw utilization in China is to return the straw to the field as fertilizer, and only $17.8 \%$ of crop straws were used for bioenergy purposes based on the 12th Five-Year Plan. $17.8 \%$ of 846.71 million tons crop straws is 150.71 million ton, and 41.83 billion $\mathrm{L}$ bioethanol could be acquired and an amount equal to 4 times China's fuel ethanol production in 2014. In fact, competition for water use between the industrial, domestic and agricultural sectors intensifies and strict water targets are imposed in different provinces, there will be a need to assess the water resources and the yields of crop straws at the provincial level. Due to large production and relatively centralized, this paper analyzes water consumption of bioethanol from maize, wheat and rice straws in major producing provinces. Taking the yields of crop straws and water resource availability into consideration, Heilongjiang, Anhui and Jiangsu provinces have rich straw resources, however local water resources have exceeded the total amount control of available water resources so that the three provinces are not suitable for developing bioethanol. Because maize, wheat and rice straws are prolific and relative-centralized, we estimate the production and water consumption in conversion of bioethanol from these in select major producer provinces (table 5). If bioethanol is produced in those provinces and $17.8 \%$ of straws were used for bioenergy purposes, 23 billion L ethanol will be produced, requiring $1.4 \times 10^{8} \mathrm{~m}^{3}$ of blue water resources. Sichuan Province is endowed with both abundant water resources and high wheat and rice straw yield and will be suitable for developing bioethanol. The situation is similar for Henan and Shandong provinces which have affluent maize and wheat straws. 
Table 5. Straw and water requirements for bioethanol in major producing provinces

\begin{tabular}{ccccc}
\hline $\begin{array}{c}\text { Crop } \\
\text { straws }\end{array}$ & Region & $\begin{array}{c}\text { Straw use } \\
(\mathbf{m i l l i o n} \\
\text { tons) }\end{array}$ & $\begin{array}{c}\text { Ethanol produced } \\
\left(\times \mathbf{1 0}^{\mathbf{9}} \text { Lethanol) }\right.\end{array}$ & $\begin{array}{c}\text { Direct water } \\
\text { requirements } \\
\left(\mathbf{1 0}^{\mathbf{6}} \mathbf{~ m}^{\mathbf{3}}\right)\end{array}$ \\
\hline & Jilin & 9.18 & 3.44 & 21.62 \\
& Shandong & 7.10 & 2.66 & 16.72 \\
Maize & Henan & 6.22 & 2.33 & 14.65 \\
straw & Inner & 6.35 & 2.38 & 14.95 \\
& Mongolia & & & \\
& Hebei & 5.87 & 2.20 & 13.82 \\
& Liaoning & 5.07 & 1.90 & 11.94 \\
& Shanxi & 3.22 & 1.21 & 7.58 \\
Wheat & Sichuan & 2.50 & 0.61 & 3.79 \\
straw & Henan & 6.22 & 1.53 & 9.44 \\
& Shandong & 4.26 & 1.05 & 6.47 \\
& Hebei & 2.62 & 0.64 & 3.98 \\
Rice & Hunan & 4.68 & 0.94 & 5.05 \\
straw & Hubei & 2.94 & 0.59 & 3.18 \\
& Sichuan & 2.73 & 0.55 & 2.95 \\
& Guangxi & 2.03 & 0.41 & 2.19 \\
\hline
\end{tabular}

\section{Conclusions}

There is current debate about whether it is reasonable to develop bioethanol at large scale because conflicts between a stable and an affordable food supply will become inevitable if water is insufficient to develop bio-ethanol at desired scale. The future barriers to bio-ethanol development in China will come from additional pressure on water resources. This paper establishes a WDWL model for quantifying water demand and supply on a regional basis that separately identifies WF in the crop growth stage and conversion stage, and provides some insights into the possible consequences of crop straws bioethanol development in terms of crop types, water availability, and geography; it may also support energy planning efforts at the national and regional scales.

Crop suitability and water scarcity are both regional factors that should be analyzed before a region commits to bioethanol development. This paper indicates that yields of straws are tremendous in China, nearly with 150.71 million tons available for bioethanol production. In addition, this study seeks to establish a database for the WFs of 10 types of crop straws in the crop growth stage and conversion stage. Among possible straw feedstocks for bioethanol production, cereal crop straws have the lowest 
WF and high yield which could be used for producing bioethanol, and it is more efficient for other crop straws to be left in the field as fertilizer or animal fodder. Water consumption is found to be much lower in the conversion stage than in the crop growth stage. Major producing provinces, such as Jilin, Shandong, Henan and Sichuan, will be the priority areas to develop bioethanol from crop straws. In major producer provinces, which are rich in maize-, wheat-and rice-straw, 23 billion L ethanol will be acquired from spare straw, and $1.4 \times 10^{8} \mathrm{~m}^{3}$ of blue water resources will be required for that conversion.

In the long run, lignocellulosic ethanol based on straws have great potential to provide a strategic sources of bioethanol from the perspective of sustainable development in terms of water resources and energy resources. Accordingly, the following recommendations are made for bio-ethanol production from crop straws: (1) To manage food and water resources well, it is difficult to spare water resources from currently cultivated crops for bio-ethanol production, so crop straws are good candidate biomass energy feedstocks. (2) As a bioethanol feedstock, cereal crop straw is clearly favorable to other crop straws yield, especially for those provinces with relatively low water stress, such as Jilin, Shandong, Henan and Sichuan Provinces. (3) Given that crop straws and water resources are distributed unevenly in China, the national strategies for bio-ethanol development should be based on a more detailed analysis considering regional water resources.

\section{References}

[1] Chiu CC, Shiang WJ, Lin CJ, Wang CH, et al: Water footprint analysis of secondgeneration bioethanol in Taiwan. J CLEAN PROD 2015; 101: 271-277.

[2] Lourinho G, Brito P: Assessment of biomass energy potential in a region of Portugal (AltoAlentejo). ENERGY 2015; 81: 189-201.

[3] Jiang D, Zhuang D, Fu J, Huang Y, Wen K: Bioenergy potential from crop residues in China: Availability and distribution. RENEW SUST ENERG REV 2012; 16: 1377-1382.

[4] Gonzalez-Salazar MA, Morini M, Pinelli M, Spina PR, et al: Methodology for estimating biomass energy potential and its application to Colombia. APPL ENERG 2014; 136: 781-796.

[5] Vávrová K, Knápek J, Weger J: Modeling of biomass potential from agricultural land for energy utilization using high resolution spatial data with regard to food security scenarios. RENEW SUST ENERG REV 2014; 35: 436-444.

[6] Važić T, Svirčev Z, Dulić T, Krstić K, et al: Potential for energy production from reed biomass in the Vojvodina region (north Serbia). RENEW SUST ENERG REV 2015; 48: 670-680.

[7] Lauri P, Havlík P, Kindermann G, Forsell N, et al: Woody biomass energy potential in 2050. ENERG POLICY 2014; 66: 19-31. 
[8] Li SZ, Chan-Halbrendt C: Ethanol production in (the) People's Republic of China: Potential and technologies. APPL ENERG 2009; 86 : S162-S169.

[9] W. GLP, L. X, J. VG, Y. HA: The blue water footprint and land use of biofuels from algae. WATER RESOUR RES 2014; 50: 8549-8563.

[10] Tian Y, Zhao L, Meng H, Sun L, Yan J: Estimation of un-used land potential for biofuels development in (the) People's Republic of China. APPL ENERG 2009; 86: 77.

[11]Elmore AJ, Shi X, Gorence NJ, Li X, et al: Spatial distribution of agricultural residue from rice for potential biofuel production in China. BIOMASS BIOENERG 2008; 32: 22-27.

[12] Wu P, Xia C, Liu F, Wu Y, et al: An integrated water strategy based on the current circumstances in China. APPL MATH MODEL 2016; 40: 8108-8124.

[13] Sun S, Wang Y, Engel BA, Wu P: Effects of virtual water flow on regional water resources stress: A case study of grain in China. SCI TOTAL ENVIRON 2016; 550: 871-879.

[14] SCPRC: No.1 Document of 2011. Beijing, China, State Council of P.R. China, 2010,

[15] Khoo HH: Review of bio-conversion pathways of lignocellulose-to-ethanol: Sustainability assessment based on land footprint projections. RENEW SUST ENERG REV 2015; 46: 100-119.

[16] Luo L, Voet EVD, Huppes G: An energy analysis of ethanol from cellulosic feedstock-Corn stover. RENEW SUST ENERG REV 2009; 13: 2003-2011.

[17] Wang YJ, Yu-Yun BI, Gao CY: The assessment and utilization of straw resources in china. Agricultural Sciences in China 2010; 9: 1807-1815.

[18] Haberl H, Erb KH, Krausmann F, Bondeau A, et al: Global bioenergy potentials from agricultural land in 2050: Sensitivity to climate change, diets and yields. BIOMASS BIOENERG 2011; 35: 4753-4769.

[19] Ruane J, Sonnino A, Agostini A: Bioenergy and the potential contribution of agricultural biotechnologies in developing countries. BIOMASS BIOENERG 2010; 34: 1427-1439.

[20] Elena GDC, Esther V: From water to energy: The virtual water content and water footprint of biofuel consumption in Spain. ENERG POLICY 2010; 38: 13451352.

[21] A H: Virtual water trade Proceedings of the International Expert Meeting on Virtual Water Trade, The Netherlands: IHE Delft, 2003,

[22] Gheewala S, Silalertruksa T, Nilsalab P, Mungkung R, et al: Water footprint and impact of water consumption for food, feed, fuel crops production in Thailand. WATER-SUI 2014; 6: 1698-1718.

[23] Wang YB, Wu PT, Engel BA, Sun SK: Application of water footprint combined with a unified virtual crop pattern to evaluate crop water productivity in grain production in China. SCI TOTAL ENVIRON 2014; 497-498:1-9. 
[24] Mekonnen MM, Hoekstra AY: The green, blue and grey water footprint of crops and derived crop products. Hydrology \& Earth System Sciences 2011; 15: 1577 1600 .

[25] Gerbensleenes W, Hoekstra AY, Theo VDM: The water footprint of bioenergy. P NATL ACAD SCI USA 2009; 106: 10219-10223.

[26] Lim CH, Lam HL: Biomass supply chain optimization via novel Biomass Element Life Cycle Analysis (BELCA). APPL ENERG 2016; 161: 733-745.

[27] Chowdhury R, Freire F: Bioenergy production from algae using dairy manure as a nutrient source: Life cycle energy and greenhouse gas emission analysis 5 . APPL ENERG 2015; 154: 1112-1121.

[28] Xu Y, Pan S, Fu G, Tian Y, Zhang X: Future potential evapotranspiration changes and contribution analysis in Zhejiang Province, East China. Journal of Geophysical Research: Atmospheres 2014; 119: 2174-2192.

[29]FAO: Crop evapotranspiration for computing crop water requirement. Fao Irrigation \& Drainage Paper 1998; 56

[30]Zheng H, Wei Y: Promote the implement of the water resources management regulation by increasing water productivity. China Water Resources 2012:24-27.

[31] Jia S, He X, Xia J: Problems and countermeasures of water resources security of China. Bulletin of Chinese Academy of Sciences 2004:347-351.

[32] Gang L, Lei S: Quantitive appraisal of biomass energy and its geographical distribution in china. Journal of Natural Resources 2007; 22: 9-19.

[33] Chiu YW, Wu M: Assessing county-level water footprints of different cellulosicbiofuel feedstock pathways. ENVIRON SCI TECHNOL 2012; 46: 9155-9162.

[34] Du F, Feng W: Progress in alcohol production from straw: A demonstration project. Modern Chemical Industry 2009:16-19.

[35] Singh S, Kumar A, Ali B: Integration of energy and water consumption factors for biomass conversion pathways. Biofuels Bioproducts \& Biorefining 2011; 5: 399-409.

[36] Yu Z: Research progress of Fuel-Ethanol production by lignocelluloses. China Biotechnology 2008; 6: 311-315.

[37] CH X: Analysis on production and application situation of fuel ethanol at home and abroad. Fine and Specialty Chemicals 2007:30-35.

[38] Andong S: Experiment research of technological processes in fuel ethanol production from lignocellulosic biomass, Henan Agricultural University, 2004,

[39]BZ Q: Development progress and prospects of cellulosic ethanol in china. CEREAL and FEED INDUSTRY 2009:11-14.

[40] Wu M, Chiu Y, Demissie Y: Quantifying the regional water footprint of biofuel production by incorporating hydrologic modeling. WATER RESOUR RES 2012; 48: 188-190.

[41] Mueller S: 2008 National dry mill corn ethanol survey. BIOTECHNOL LETT 2010; 32: 1261-1264. 
[42] Gallagher PWAH: Usda's 2002 Ethanol Cost-Of-Production Survey, Staff General Research Papers, 2005,

[43] Wu M: Analysis of the efficiency of the U.S. Ethanol industry 2007. Argonne National Laboratory 2008

[44] Hong Y, Yuan Z, Liu J: Land and water requirements of biofuel and implications for food supply and the environment in China. ENERG POLICY 2009; 37: 18761885.

[45] Fingerman KR, Torn MS, O'Hare MH, Kammen DM: Accounting for the water impacts of ethanol production. ENVIRON RES LETT 2010; 3362: 207-238.

[46] Ning Miao JNZY: Analysis on water resource demand and its support degree for developing bio-energy in china. China Soft Science 2009:11-18. 